\title{
Biodegradability assessment of \\ starch/glycerol foam and poly(butylene \\ adipate-co-terephthalate)/starch film by \\ respirometric tests
}

\section{Avaliação da biodegradabilidade de espuma de amido/glicerol e de filme de poli(butileno adipato-co-tereftalato)/amido em \\ testes respirométricos}

\author{
Ivan Taiatele Junior ${ }^{1,2 *}$, Tatiane Cristina Dal Bosco ${ }^{1}$, Janksyn Bertozzi ${ }^{3}$, \\ Roger Nabeyama Michels ${ }^{4}$, Suzana Mali ${ }^{5}$ (I)
}

${ }^{1}$ Universidade Tecnológica Federal do Paraná (UTFPR), Departamento de Engenharia Ambiental, Londrina/PR -

Brasil

${ }^{2}$ Universidade Estadual de Londrina (UEL), Centro de Tecnologia e Urbanismo, Departamento de Engenharia Civil,

Londrina/PR - Brasil

${ }^{3}$ Universidade Tecnológica Federal do Paraná (UTFPR), Departamento de Química, Londrina/PR - Brasil

${ }^{4}$ Universidade Tecnológica Federal do Paraná (UTFPR), Departamento de Engenharia Mecânica, Londrina/PR -

Brasil

${ }^{5}$ Universidade Estadual de Londrina (UEL), Centro de Ciências Exatas, Departamento de Bioquímica e

Biotecnologia, Londrina/PR - Brasil

${ }^{*}$ Corresponding Author: Ivan Taiatele Junior, Universidade Estadual de Londrina (UEL), Centro de Tecnologia e Urbanismo, Departamento de Engenharia Civil, Rodovia Celso Garcia Cid, PR-445, Km 380, Campus Universitário, CEP: 86057-970, Londrina/PR - Brasil, e-mail: taiatele.ivan@gmail.com

Cite as: Taiatele Junior, I., Dal Bosco, T. C., Bertozzi, J., Michels, R. N., \& Mali, S. (2020). Biodegradability assessment of starch/glycerol foam and poly(butylene adipate-co-terephthalate)/starch film by respirometric tests. Brazilian Journal of Food Technology, 23, e2018248. https://doi.org/10.1590/1981-6723.24818

\begin{abstract}
The objectives of this work were to determine the biodegradability of starch/glycerol foam and of poly(butylene-adipate-co-terephthalate) (PBAT)/starch film using respirometric methods and also to compare these results with conventional polymers - expanded polystyrene and low-density polyethylene. A matured organic compost was utilized as inoculum and sucrose was used as positive reference material. Biodegradation efficiencies (BE) after 47 days were: 35\% for sucrose; 34\% for starch/glycerol; and 38\% for PBAT/starch. Starch/glycerol and PBAT/starch presented BE statistically equal to sucrose, whilst both the conventional packaging used were not degraded $(p>0.05)$. Infrared spectroscopy and thermogravimetric analyses showed that the microbiota rather degraded the starch over the PBAT in the PBAT/starch blend, and also that some starch remained intact in the internal polymeric matrix. This study verified that starch/glycerol foam and PBAT/starch film are highly biodegradable materials and may then be used to enhance the biodegradability of some products such as disposable trays and supermarket bags.
\end{abstract}

Keywords: Biopolymers; PBAT; Sturm; Thermoplastic; Starch; Composting. 


\section{Resumo}

Os objetivos do presente estudo foram determinar a biodegradabilidade de espuma de amido/glicerol e de filme de poli(butileno-adipato-co-tereftalato)(PBAT)/amido usando métodos respirométricos e também comparar esses resultados com os de polímeros convencionais - poliestireno expandido e polietileno de baixa densidade. Um composto orgânico maturado foi utilizado como inóculo e sacarose foi utilizada como material de referência positiva. As eficiências de biodegradação (EB) após 47 dias foram: 35\% para a sacarose; 34\% para o amido/glicerol; $38 \%$ para o PBAT/amido. O amido/glicerol e o PBAT/amido apresentaram EB estatisticamente iguais à da sacarose, enquanto as embalagens convencionais não foram degradadas $(p>0,05)$. Espectroscopia de infravermelho e análises termogravimétricas mostraram que a microbiota deu preferência à degradação do amido em detrimento do PBAT na blenda PBAT/amido e também que parte do amido permaneceu intacta na matriz polimérica interna. Foi verificado que espuma de amido/glicerol e filme de PBAT/amido são embalagens altamente biodegradáveis, portanto podem ser usadas para aumentar a biodegradabilidade de alguns produtos, como bandejas descartáveis e sacolas plásticas de supermercado.

Palavras-chave: Biopolímeros; PBAT; Sturm; Termoplástico; Amido; Compostagem.

\section{Introduction}

The demand for plastic polymers is getting higher and higher nowadays since these materials are present in the composition of a wide range of manufactured products. Once discarded after use, these products consist of non-biodegradable waste that is often disposed of in sanitary landfills where they can cause soil and groundwater contamination. Moreover, most of these polymers come from non-renewable resources, especially oil, whose extracting and refining processes cause severe environmental impacts (Razza et al., 2015; Harun-Or-Rashid et al., 2015; Brito et al., 2011). Biodegradable materials with similar properties to conventional polymers are being developed in an attempt to partially replace the latter and hence minimize the impacts on the environment. Some of these novel polymers are not only biodegradable but also compostable, which makes it possible to discard them along with organic waste in order to be recycled by composting instead of being disposed of in landfills. There is research and development of some biodegradable packaging using raw materials from renewable resources (biopolymers) such as starch, cellulose, chitosan, gelatin, poly(vinyl alcohol) (PVA), poly(lactic acid) (PLA), poly(butylene succinate) (PBS), etc., which makes them even more environmentally friendly due to their shorter life cycles compared to those from non-renewable resources (Frackowiak et al., 2016; Ahmed \& Ikram, 2016; Razza et al., 2015; Harun-Or-Rashid et al., 2015; Brito et al., 2011; Associação Brasileira de Normas Técnicas, 2008).

Starch is a biopolymer widely employed by researchers aiming to increase the biodegradability of several products conventionally manufactured with non-biodegradable polymers (Versino et al., 2016; Bonilla et al., 2013; Campos et al., 2011; Belgacem \& Gandini, 2008). Starch needs the presence of a plasticizer agent to be processed. Water and glycerol are two of the most typical plasticizers used in the production of processed materials, and the mixture of both with starch yields the thermoplastic starch, or TPS (Krishnan et al., 2017; Noorizzaha et al., 2016; Chiou et al., 2005; Halley, 2005).

Several items can be produced from TPS, such as foams (expanded TPS), films, bags, etc. TPS has been particularly designed to produce foam trays by thermoforming processes. Starch trays are able to substitute for instance expanded polystyrene (EPS) trays in some cases where they are to be quickly discarded after use. This could solve several waste management problems since EPS is not biodegradable, and also not very dense - which makes it difficult to be recycled - besides the fact that its raw material is non-renewable (Carvalho et al., 2018; Marcelino et al., 2016; Debiagi et al., 2015; Mello \& Mali, 2014; Silva et al., 2013; Vercelheze et al., 2013; Matsuda et al., 2013; Marengo et al., 2013).

Starch can be used in blends with other polymers. Benefits can be gained even when it is associated with non-biodegradable polymers. Li et al. (2011) conducted respirometric tests on TPS, poli(lactic acid) (PLA), 
low-density polyethylene (LDPE) and on TPS/PLA and TPS/LDPE blends. The results showed no significant biodegradation for pure PLA and LDPE polymers, but the blends increased the degradation for the TPS portion compared to pure TPS (Li et al., 2011).

Starch can still be blended with other biodegradable polymers, such as poly(butylene adipate-co-terephthalate), or PBAT, whose properties are very similar to many other oil-based plastics (Muniyasamy et al., 2013). PBAT can be used in several applications such as blown films and membrane coproducts (Weng et al., 2013). Since starch is a biopolymer, its association with PBAT can even enhance environmental benefits. In fact, PBAT/starch blend has been used for the development of films with biodegradability and compostability properties, as an alternative to conventional non-biodegradable bags made of LDPE (Garcia et al., 2014, 2018; Cardoso et al., 2018; Olivato et al., 2013, 2014; Brandelero et al., 2013; Nobrega et al., 2013).

The aim of this study was to assess the biodegradability of starch packaging with different applications and compositions, such as starch/glycerol foam tray and PBAT/starch bag, in order to support and encourage the development and usage of these "green" products.

\section{Material and methods}

\subsection{Material}

Starch/glycerol trays were produced and kindly supplied by the Department of Biochemistry and Biotechnology - State University of Londrina. For the production of the trays, the ingredients utilized were cassava starch (Yoki Alimentos S/A, Brazil), glycerol (P.A. ${ }^{1}$, Reagen, Brazil), magnesium stearate (P.A., Labsynth, Brazil,), guar gum (P.A., Labsynth, Brazil) and distilled water. PBAT/starch film was produced and kindly supplied by the Department of Food Science and Technology - State University of Londrina. The packaging was formulated using starch (Indemil, Brazil), glycerol (P.A., Dinâmica, Brazil), poly (butylene adipate-co-terephthalate) or PBAT - under commercial name Ecoflex ${ }^{\circledR}-\mathrm{F}$ (BASF, Germany) and citric acid (P.A., Sigma-Aldrich, USA). Sucrose was used as a positive reference material. Expanded polystyrene (EPS) trays and low-density polyethylene (LDPE) bags were obtained from a packaging shop and used as a negative control to represent conventional polymers (negative reference materials) in comparison with biodegradable ones (starch/glycerol and PBAT/starch, respectively). Five treatments (samples) were then tested: sucrose (T1), starch/glycerol foam tray (T2), PBAT/starch film (T3), EPS tray (T4) and LDPE bag (T5).

\subsection{Methods}

\subsubsection{Packaging manufacturing}

Foam formulation was prepared by putting starch $(100 \mathrm{~g})$, distilled water $(100 \mathrm{~mL})$ and other additives - magnesium stearate and guar gum (1 g each) - in a mechanical overhead stirrer (Fisatom 715, Brazil). All ingredients were mixed for $5 \mathrm{~min}$, and glycerol $(5 \mathrm{~g})$ was then added. After stirring for another $5 \mathrm{~min}, 80 \mathrm{~g}$ of the formulation were homogeneously spread over a $235 \mathrm{~mm}$ long, $180 \mathrm{~mm}$ wide and $20 \mathrm{~mm}$ deep Teflon mold with a $1.0 \mathrm{~mm}$ thick metallic guide. A Teflon lid was placed over the mixture, and thermopressing was performed with a hydraulic press (JOMAQ, São Paulo, Brazil) equipped with an electric heating system, a Pt100 temperature sensor and a PID (proportional-integral-derivative) controller. One pressing step was performed at $150{ }^{\circ} \mathrm{C}$ to $160{ }^{\circ} \mathrm{C}$ for $7 \mathrm{~min}$ and 100 bars of pressure was applied to the top part of the mold. Finally, the mold was removed from the hydraulic press, the tray was released from the mold and stored at room temperature (Vercelheze et al., 2013).

\footnotetext{
${ }^{1}$ Purity grade, were P.A. stands for "pro analyse" and ACS stands for American Chemical Society grade.
} 
The films were manufactured using a laboratory mono-screw extruder (model EL-25, BGM, São Paulo, Brazil). The screw has the specifications: $\mathrm{D}=25 \mathrm{~mm}, \mathrm{~L}=26 \mathrm{D}$, gap widths 22.2 and $14.4 \mathrm{~mm}$ at the feed and final zones, respectively, the pitch of $24.6 \mathrm{~mm}$, compression ratio 1:1.6. The extruder has four heating zones for pellets production and five for film production. Firstly, $200 \mathrm{mg}$ of citric acid were dissolved in $170 \mathrm{~g}$ of glycerol and then manually mixed with the PBAT and cassava starch (200 and $630 \mathrm{~g}$, respectively), before extrusion. The films were produced in two stages. In the first stage, for the pellet production, the mixture was extruded through a die with six $2 \mathrm{~mm}$ diameter holes at temperatures of $90 / 120 / 120 / 120{ }^{\circ} \mathrm{C}$ from the feeding zone to the die zone and at a screw speed of $40 \mathrm{rpm}$. Then, the pellets were extruded again to obtain the blown film, using the same mono-screw extruder, with a temperature profile of $90 / 120 / 120 / 130{ }^{\circ} \mathrm{C}$ at the four zones and $130{ }^{\circ} \mathrm{C}$ for the $50-\mathrm{mm}$ film-blowing die, at the same screw speed (40 rpm) and with rolls speed of $10 \mathrm{rpm}$. These conditions were determined in previous studies (Garcia et al., 2014).

\subsubsection{Preparation of samples and inoculum}

All packaging materials were fragmented into $2 \times 2 \mathrm{~cm}$ pieces. Thickness was maintained as from each original material: $2.12 \pm 0.04 \mathrm{~mm}$ for starch tray; $124 \pm 23 \mu \mathrm{m}$ for PBAT/starch film; $2.7 \mathrm{~mm}$ for EPS tray; and $100 \mu \mathrm{m}$ for LDPE film. The inoculum utilized for this study was a stabilized and matured organic compost, obtained from the composting process of sludge from a wastewater treatment plant of dairy industry with tree pruning residues. Large wood particles were removed from the compost, which was then sieved on a screen of $0.5 \mathrm{~cm}$, following requirements of the standard ISO 14855-2 (International Organization for Standardization, 2007).

\subsubsection{Characterization of samples and inoculum}

Initial analyses were held for determining moisture content, total solids, fixed solids, volatile solids (American Public Health Association, 2012) and total nitrogen (Malavolta et al., 1997) of each polymeric material in study - EPS, LDPE, starch/glycerol foam and PBAT/starch film - besides sucrose, utilized as a positive reference material, and the compost, used as inoculum. For determination of moisture and total solids, $5 \mathrm{~g}$ of each sample were weighted, placed in an oven at $105^{\circ} \mathrm{C}$ for $24 \mathrm{~h}$ and then weighted again. The remaining residues were placed in a muffle furnace at $550{ }^{\circ} \mathrm{C}$ for $2 \mathrm{~h}$ and a final weighing was made in order to obtain fixed solids and volatile solids contents (American Public Health Association, 2012). Total Organic Carbon contents were then estimated using the equation [TOC $=(0.425 * \mathrm{VS})-2.064]$, where VS is the volatile solids content in the sample (Carmo \& Silva, 2012).

For the determination of total nitrogen, samples were dried in an oven at $50{ }^{\circ} \mathrm{C}$ for $48 \mathrm{~h}$ and then macerated. Afterwards, $0.2 \mathrm{~g}$ of each sample was inserted in test tubes, and hydrogen peroxide (1 mL, P.A., Alphatec), concentrated sulphuric acid (2 mL, P.A., Alphatec) and digester mixture $(0.7 \mathrm{~g})$ - selenium (P.A., Vetec), $\mathrm{CuSO}_{4}$ (P.A.-ACS, Vetec), and $\mathrm{NaSO}_{4}$ (P.A.-ACS, Quimica Moderna), at mass ratio of 1:10:100 - were respectively added to the tubes. The solutions were then digested in a heating block, whose temperature was gradually increased by $50{ }^{\circ} \mathrm{C}$ every 30 minutes until it reached $350{ }^{\circ} \mathrm{C}$ when the tubes were kept inside the block for another hour before it was turned off. Once the tubes were cool, $10 \mathrm{~mL}$ of distilled water were added and distillation was performed for final solutions using a Kjeldahl distiller. Boric acid (P.A.-ACS, Alphatec, $5 \mathrm{~mL}$ ) was used as an acid-base indicator and added to a recipient where $30 \mathrm{~mL}$ of distilled sample were collected. Titration was performed with $\mathrm{H}_{2} \mathrm{SO}_{4} 0.025 \mathrm{M}$, and the volume of consumed acid (Vs) was used to calculate the total nitrogen content using the Equation 1.

$\mathrm{N}(\%)=\frac{\left(\mathrm{V}_{\mathrm{s}}-\mathrm{V}_{\mathrm{b}}\right) \times 0.7 \times\left(\frac{1}{\mathrm{DS}_{\mathrm{s}}}\right)}{10}$ 
where $\mathrm{N}$ is the total nitrogen content, in percentage; $\mathrm{V}_{\mathrm{b}}$ is the volume of consumed acid for the blank, in $\mathrm{mL}$; and $\mathrm{DS}_{\mathrm{s}}$ are the total dry solids in the sample, in grams (Malavolta et al., 1997).

For the compost, $\mathrm{C} / \mathrm{N}$ ratio and $\mathrm{pH}$ (Tedesco et al., 1995) were determined, the latter being desired to be between 7.0 and 9.0 in order to ensure an environment favorable to the development of the microorganisms involved in the degradation of organic matter (International Organization for Standardization, 2007).

\subsubsection{Biodegradability tests (Sturm Tests)}

The system set-up was based on the instructions of ISO 14855-2:2007 with some adaptation. A set of three plastic flasks was utilized for each polymer (Figure 1). The atmospheric air coming from a compressor flows into the flask $\mathrm{A}$, which works as a carbon dioxide scrubber, containing $150 \mathrm{~mL}$ of sodium hydroxide (P.A.-ACS, Alphatec) $6.0 \mathrm{~mol} \mathrm{~L}^{-1}$. $\mathrm{CO}_{2}$-free air is then pumped to flask $\mathrm{B}$, which works as a reactor, storing the test mixture - inoculum + polymer - at the proportion of $6: 1 \mathrm{v} / \mathrm{v}(300 \mathrm{~mL}$ of inoculum and $50 \mathrm{~mL}$ of polymer). Finally, the carbon dioxide that has been derived from the aerobic biodegradation in flask $\mathrm{B}$ is collected in flask $\mathrm{C}$, containing $100 \mathrm{~mL}$ of $\mathrm{NaOH} 0.5 \mathrm{~mol} \mathrm{~L}^{-1}$.

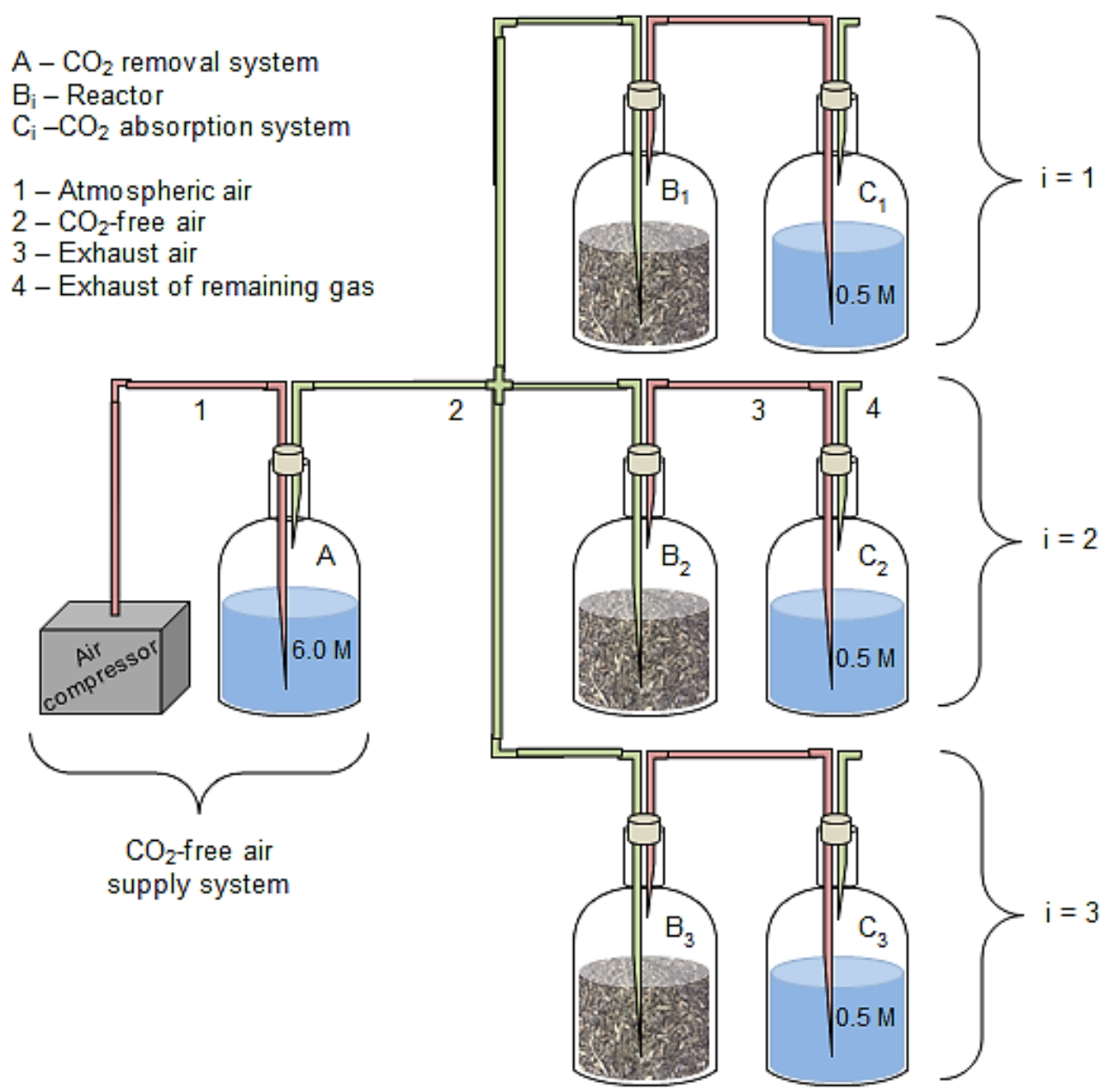

Figure 1. Experimental apparatus for the Sturm Test.

In order to guarantee favorable conditions to aerobic microorganisms, moisture content of the test mixture shall be around 50\% (International Organization for Standardization, 2007). During the test, the maintenance of moisture content was done by the solution inside flask A, which humidifies the air before reaching the reactor. 
Each test was held in triplicate, in order to avoid random errors. The $\mathrm{CO}_{2}$-free air supply system (compressor + flask A) (Figure 1), however, was only one for all replications of the same test, being enough for feeding all three reactors. Six sets similar to that (in Figure 1) were utilized in total: one for each packaging in test (totaling four); one for the positive reference material (sucrose); and one containing only the compost used as inoculum, consisting in the control. The whole system was kept at room temperature for 47 days.

\subsubsection{Carbon dioxide evolution analysis}

During the first 31 days of the test, aliquots of solutions from flasks C (Figure 1) were collected daily ( $24 \mathrm{~h}$ of interval). Two extra samplings occurred at 39 and 47 days of the test, each representing 8 days of $\mathrm{CO}_{2}$ evolution. Dissolved $\mathrm{CO}_{2}$ amounts, corresponding to what has evolved in the period between samplings, were posteriorly determined in the aliquots. This determination was made by the Flow Injection Analysis method (FIA) (Kawazaki et al., 2000). A $100 \mathrm{~mL}$ quantity of $\mathrm{NaOH} 0.5$ mol. $\mathrm{L}^{-1}$ solution was added to flasks $\mathrm{C}$ (Figure 1), which were immediately reinstalled to the closed system.

The total cumulative $\mathrm{CO}_{2}$ evolved at the end of 47 days were compared among all treatments. For this comparison, the ratio between the total cumulative $\mathrm{CO}_{2}$ evolved and the polymer mass inserted in each flask was calculated, obtaining the parameter of cumulative $\mathrm{CO}_{2}$ mass per sample mass $\left(\mathrm{mg} \mathrm{g}^{-1}\right)$.

\subsubsection{Calculation of the biodegradation efficiency}

From the cumulative mass of carbon dioxide evolved over $t$ days of the biodegradation process of the packaging, it was possible to calculate its Biodegradation Efficiency $\left(\mathrm{BE}_{\mathrm{t}}\right)$, using Equations 2 and 3 (International Organization for Standardization, 2007).

$$
\mathrm{BE}_{\mathrm{t}}=\frac{\left(\mathrm{mC}_{\mathrm{P}}-\mathrm{mC}_{\mathrm{C}}\right)}{\mathrm{mC}_{\mathrm{T}}} \times 100
$$

where $\mathrm{BE}_{\mathrm{t}}$ is the Biodegradation Efficiency, in percentage; $\mathrm{mC}_{\mathrm{P}}$ is the cumulative mass of carbon dioxide evolved by biodegradation process of certain treatment $(\mathrm{g}) ; \mathrm{mC}_{\mathrm{C}}$ is the mean cumulative mass of carbon dioxide evolved by the control flasks $(\mathrm{g})$; and $\mathrm{mC}_{\mathrm{T}}$ is the theoretical mass of carbon dioxide $(\mathrm{g}$ ) (obtained from Equation 3).

$\mathrm{mC}_{\mathrm{T}}=\mathrm{DS} \times \mathrm{C}_{\mathrm{org}} \times \frac{44}{12}$

where DS is the total dry solids of packaging introduced into reactors at the beginning of the test ( $\mathrm{g})$; $\mathrm{C}_{\text {org }}$ is the proportion of total organic carbon in the total dry solids of packaging $\left(\mathrm{g} \mathrm{g}^{-1}\right)$; and 44 and 12 are the molecular mass of carbon dioxide and the atomic mass of carbon, respectively.

The values of $\mathrm{mC}_{\mathrm{T}}$ that could be evolved from each reactor are demonstrated in Table 1. The fact that these values vary a lot depending on the material reinforces the importance of utilizing this parameter in the calculation of the $\mathrm{BE}_{\mathrm{t}}$.

Table 1. Theoretical mass of $\mathrm{CO}_{2}\left(\mathrm{mC}_{\mathrm{T}}\right)$.

\begin{tabular}{ccc}
\hline Material (Treatment) & Dry mass (g) & Theoretical CO $_{\mathbf{2}} \mathbf{( g )}^{\mathbf{b} ; \mathbf{c}}$ \\
\hline Sucrose (T1) & $44.994 \pm 0.026$ & $66.643 \pm 0.039^{\mathrm{A}}$ \\
\hline Starch/glycerol foams (T2) & $6.169 \pm 0.006$ & $9.137 \pm 0.009^{\mathrm{C}}$ \\
\hline PBAT/starch films (T3) & $13.168 \pm 0.029$ & $19.510 \pm 0.043^{\mathrm{B}}$ \\
\hline EPS trays (T4) & $0.703 \pm 0.004$ & $1.041 \pm 0.006^{\mathrm{D}}$ \\
\hline LDPE bags (T5) & $0.505 \pm 0.008$ & $0.721 \pm 0.011^{\mathrm{E}}$ \\
\hline
\end{tabular}

${ }^{\mathrm{a}}$ Total mass of polymer multiplied by total dry solids content. ${ }^{b}$ Values obtained from Equation 3. ${ }^{\mathrm{c}}$ Common capital letters within columns denote the absence of a significant difference $(p>0.05)$. 


\subsubsection{Thermal and structural analyses}

Thermal and structural analyses of starch/glycerol foams, PBAT/starch films, EPS trays and LDPE bags were carried out at the beginning and at the end of the biodegradation tests using thermogravimetric analyses (TGA) and Fourier transform - infrared spectroscopy (FT-IR), which occurred at the Spectroscopy Laboratory - ESPEC, at the Multiuser Laboratories Centre of State University of Londrina (UEL).

For FT-IR, the samples were dried and compressed into tablets with potassium bromide. The FT-IR analyses were performed with a Shimadzu FT-IR 8300 (Shimadzu, Japan), which has a spectral resolution of $4 \mathrm{~cm}^{-1}$ and a spectral range of 4000 to $500 \mathrm{~cm}^{-1}$.

Thermogravimetric analyses (TGA 50 - Shimadzu - Japan) were carried out under a nitrogen atmosphere $\left(50 \mathrm{~mL} \mathrm{~min}^{-1}\right)$, and the samples (approximately $5 \mathrm{mg}$ ) were heated from room temperature $\left(20^{\circ} \mathrm{C}\right.$ to $30{ }^{\circ} \mathrm{C}$ ) to $600{ }^{\circ} \mathrm{C}$ at a heating rate of $10^{\circ} \mathrm{C} \mathrm{min}^{-1}$. The weight loss (\%) was evaluated by measuring the residual weight at $600^{\circ} \mathrm{C}$.

\subsection{Statistical analyses}

The data were analyzed using SISVAR software, with an analysis of variance (ANOVA) and Scott-Knott test at a $5 \%$ significance level.

\section{Results and discussion}

\subsection{Initial characterization of samples and inoculum}

Initial characterization of polymers and inoculum is shown in Table 2. Sucrose, EPS and LDPE presented moisture contents very close or equal to zero, while biodegradable polymers have moisture values around $12 \%$, which is possibly due to the hydrophilic character of starch and glycerol employed in formulations of these materials. The initial moisture of the compost was about $63 \%$, which is a suitable moisture level for thermo-composting according to Kiehl (2004).

Table 2. Initial characterization of sucrose, polymers and inoculum (compost).

\begin{tabular}{ccccccc}
\hline Sample & $\begin{array}{c}\text { Moisture } \\
(\mathbf{\%})^{\mathbf{a}}\end{array}$ & $\begin{array}{c}\text { Total Dry } \\
\text { Solids (\%) }\end{array}$ & $\begin{array}{c}\text { Fixed Solids } \\
\mathbf{( \% )}^{\mathbf{a}}\end{array}$ & $\begin{array}{c}\text { Volatile } \\
\text { Solids (\%) }\end{array}$ & $\begin{array}{c}\text { Total } \\
\text { Organic } \\
\text { Carbon } \\
\mathbf{( \% )}^{\mathbf{a}}\end{array}$ & $\begin{array}{c}\text { Total } \\
\text { Nitrogen } \\
(\%)^{\mathbf{a}}\end{array}$ \\
\hline Sucrose (T1) & $0.27^{\mathrm{C}}$ & $99.73^{\mathrm{A}}$ & $0.09^{\mathrm{C}}$ & $99.91^{\mathrm{A}}$ & $40.40^{\mathrm{A}}$ & $0.00^{\mathrm{B}}$ \\
\hline Starch/glycerol foam (T2) & $12.16^{\mathrm{B}}$ & $87.84^{\mathrm{B}}$ & $0.10^{\mathrm{C}}$ & $99.90^{\mathrm{A}}$ & $40.39^{\mathrm{A}}$ & $0.00^{\mathrm{B}}$ \\
\hline PBAT/starch film (T3) & $12.41^{\mathrm{B}}$ & $87.59^{\mathrm{B}}$ & $0.06^{\mathrm{C}}$ & $99.94^{\mathrm{A}}$ & $40.41^{\mathrm{A}}$ & $0.00^{\mathrm{B}}$ \\
\hline EPS tray (T4) & $0.00^{\mathrm{C}}$ & $100.00^{\mathrm{A}}$ & $0.12^{\mathrm{C}}$ & $99.88^{\mathrm{A}}$ & $40.38^{\mathrm{A}}$ & $0.00^{\mathrm{B}}$ \\
\hline LDPE bag (T5) & $0.72^{\mathrm{C}}$ & $99.28^{\mathrm{A}}$ & $3.49^{\mathrm{B}}$ & $96.51^{\mathrm{B}}$ & $38.95^{\mathrm{B}}$ & $0.00^{\mathrm{B}}$ \\
\hline Compost (inoculum) & $62.92^{\mathrm{A}}$ & $37.08^{\mathrm{C}}$ & $19.51^{\mathrm{A}}$ & $80.49^{\mathrm{C}}$ & $32.14^{\mathrm{C}}$ & $2.86^{\mathrm{A}}$ \\
\hline
\end{tabular}

${ }^{\mathrm{a} C o m m o n}$ capital letters within columns denote the absence of significant difference $(p>0.05)$.

Volatile solids represent nearly the totality of dry mass for all tested materials, i.e. volatile solids contents about $100 \%$, the lowest one being related to LDPE (96.51\%). This is reflected in Total Organic Carbon (TOC) contents (Table 2), which were around $40 \%$ for sucrose, starch/glycerol foams, PBAT/starch films and EPS, and for LDPE this value was significantly lower $(p<0.05)$. The lowest value for TOC was observed for the compost (32.14\%) (Table 2).

The total nitrogen analysis demonstrated that $2.86 \%$ of the compost composition comprises this element (Table 2), and thus its $\mathrm{C} / \mathrm{N}$ ratio is 11.24:1, typical value for a matured compost obtained at the end of a 
composting process. Lastly, it was not detected the presence of nitrogen either in the polymeric materials or in sucrose.

The $\mathrm{pH}$ of the compost was found to have a value of 6.73 , very close to the interval of 7.0 to 9.0 that International Organization for Standardization (2007) recommends for the inoculum so it creates a favorable ambient for the development of the microorganisms.

\subsection{Carbon dioxide evolution}

Daily $\mathrm{CO}_{2}$ evolution values were added for each treatment, resulting in cumulative evolution values over 47 days of duration (Table 3). The values represent the balance of carbon dioxide evolved by each treatment when discounting the evolution by the control. Once the mass of polymer inserted for each treatment varied, the ratio between the cumulative $\mathrm{CO}_{2}$ and the sample mass was also calculated.

Table 3. Total cumulative $\mathrm{CO}_{2}$ mass at the end of the tests (47 days) per gram of sucrose or polymer.

\begin{tabular}{|c|c|c|c|}
\hline Material/Treatment & $\begin{array}{c}\text { Cumulative } \mathrm{CO}_{2} \\
\text { mass (mg) }{ }^{\text {a;b }}\end{array}$ & Sample mass (g) & $\begin{array}{l}\text { Cumulative } \mathrm{CO}_{2} \text { mass/ } \\
\text { sample mass }\left(\mathrm{mg} \mathrm{g}^{-1}\right)^{\mathrm{a} ; \mathrm{b}}\end{array}$ \\
\hline Sucrose (T1) & $23353.73 \pm 2267.55^{\mathrm{A}}$ & $45.12 \pm 0.03$ & $517.66 \pm 50.50^{\mathrm{A}}$ \\
\hline Starch/glycerol foams (T2) & $3095.80 \pm 786.63^{\mathrm{C}}$ & $7.02 \pm 0.01$ & $440.74 \pm 111.88^{\mathrm{A}}$ \\
\hline PBAT/starch films (T3) & $7433.58 \pm 870.64^{\mathrm{B}}$ & $15.03 \pm 0.03$ & $494.48 \pm 57.78^{\mathrm{A}}$ \\
\hline EPS trays (T4) & $(1160.03) \pm 96.12^{\mathrm{D}}$ & $0.70 \pm 0.00$ & $(1649.64) \pm 134.00^{\mathrm{C}}$ \\
\hline LDPE bags (T5) & $(482.26) \pm 161.26^{\mathrm{D}}$ & $0.51 \pm 0.01$ & $(951.86) \pm 331.60^{\mathrm{B}}$ \\
\hline
\end{tabular}

${ }^{\mathrm{a}} \mathrm{Common}$ capital letters within columns denote the absence of significant difference $(p>0.05)$. ${ }^{\mathrm{b}}$ Values between brackets stand for $\mathrm{CO}_{2}$ evolution lower than control.

For cumulative $\mathrm{CO}_{2}$ results, either the positive reference material (sucrose-T1) or the biodegradable polymers (T2 and T3) obtained positive balances at the end of the test, behavior expected due to the presence of readily degradable organic matter. Treatments T4 and T5, where conventional (non-biodegradable) polymers were inserted, evolved less $\mathrm{CO}_{2}$ than the control, resulting in a negative balance. There is a significant difference among all treatments, except between $\mathrm{T} 4$ and $\mathrm{T} 5$.

For the ratios observed in the last column of Table 3, the difference between sucrose and biodegradable polymers become no longer significant $(p>0.05)$. This is an indication that both biodegradable polymers reached biodegradation efficiencies as high as that for the positive reference material at the end of 47 days, which will be confirmed by the results posteriorly presented.

Diverse values can be found in the literature for total mass of $\mathrm{CO}_{2}$ accumulated over respirometric tests for different materials. In general, polymers that have starch in their composition present good performance during biodegradation studies and evolve high quantities of $\mathrm{CO}_{2}$ (Kijchavengkul et al., 2006; Vinhas et al., 2007). Kijchavengkul et al. (2006) found cumulative $\mathrm{CO}_{2}$ values around $1,400 \mathrm{mg} \mathrm{g}^{-1}$ of pure corn starch incubated at $58 \pm 2{ }^{\circ} \mathrm{C}$ for 47 days. Vinhas et al. (2007) observed $\mathrm{CO}_{2}$ evolution of about 0.85 and $1.5 \mathrm{~g}$ for PHB-HV/starch and PHB/starch, respectively, incubated for 28 days, but they did not mention initial sample masses.

It is important to highlight that experimental conditions may vary among different studies, such as inoculum/polymer proportion, temperature of incubation, air flow rate, test duration, method of measuring the trapped $\mathrm{CO}_{2}$, etc. These conditions directly interfere with final results of $\mathrm{CO}_{2}$ evolution and must be considered when comparing data from the literature.

\subsection{Biodegradation efficiency}

The calculation of Biodegradation Efficiency (BE) was utilized in order to normalize all treatments in relation to their respective theoretical $\mathrm{CO}_{2}$ amounts. In other words, comprehending the $\mathrm{BE}$ of a certain polymer allows identifying the portion of organic matter (TOC) of this material that was effectively degraded and converted to carbon dioxide during the test period. 
From masses of theoretical $\mathrm{CO}_{2}$ (Table 1) and utilizing Equation 2, values of $\mathrm{BE}_{\mathrm{t}}$ were calculated for sucrose and the biodegradable polymers (Figure 2). This parameter was not calculated for conventional polymers (T4 and T5) since they only worked as a negative reference and previous results already proved the absence of biodegradability $\left(\mathrm{CO}_{2}\right.$ evolution lower than control).

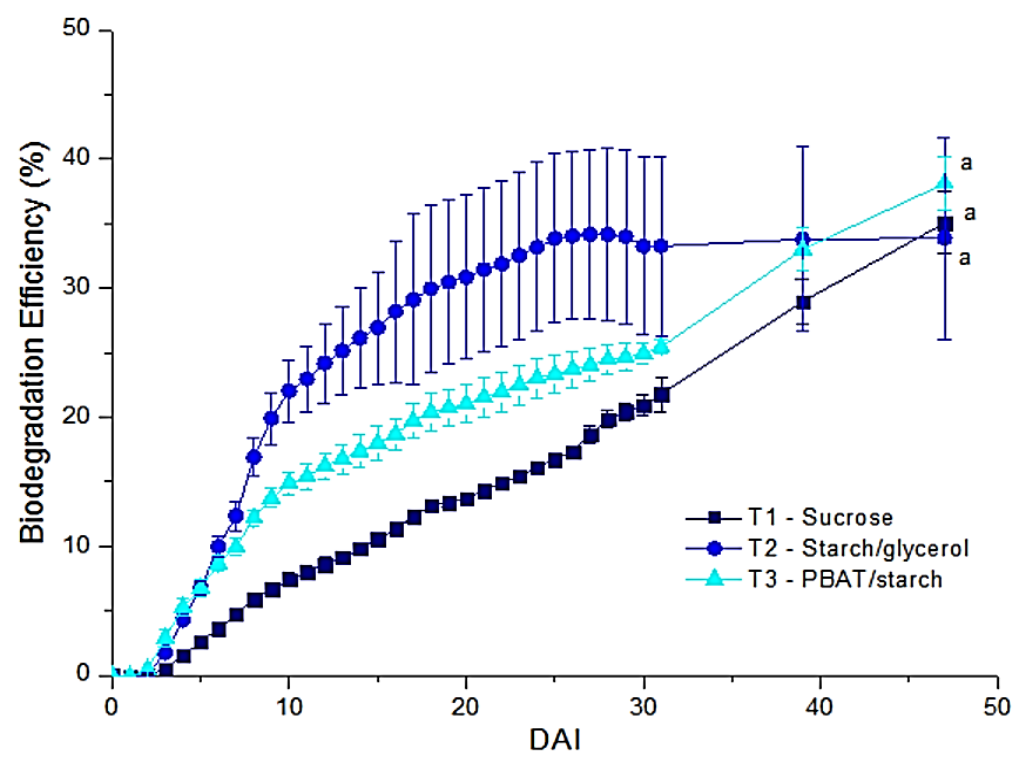

Figure 2. Biodegradation Efficiency of the packaging in the study. Notes: DAI = Days After Incubation. Different letters in the same phase represent significantly different values $(p<0.05)$.

Ever-increasing $\mathrm{BE}_{\mathrm{t}}$ values were observed for $\mathrm{T} 1$ and $\mathrm{T} 3$ during the 47 days of tests, but not for $\mathrm{T} 2$, whose values were kept nearly constant from 27DAI onwards. In other words, T2 has reached a plateau phase for $\mathrm{BE}$ earlier than $\mathrm{T} 1$ and $\mathrm{T} 3$, which means that the biodegradable portion of starch/glycerol foam was more readily available to the microorganism compared to sucrose and PBAT/starch film. In fact, BE for T2 became visually higher than $\mathrm{BE}$ for $\mathrm{T} 1$ and $\mathrm{T} 3$ after one week of the experiment (at 8DAI) and kept this behavior until 31DAI, when T3 reached similar values. Additionally, for the conditions applied in this study, $\mathrm{T} 1$ and $\mathrm{T} 3$ would only have reached the plateau phase if the tests lasted longer.

At the end of the 47 days of the test, BE for T1, T2 and T3 reached 35, 34 and 38\%, respectively, which demonstrates the good performance obtained by the biodegradable polymers ( $\mathrm{T} 2$ and $\mathrm{T} 3$ ), very close to that obtained by the positive reference material (sucrose-T1). It is important to note that the standard deviation (SD) tends to increase over the test for all treatments since BE calculation involves cumulative parameters. SD values were particularly high for $\mathrm{T} 2$, reaching around $8 \%$ at $47 \mathrm{DAI}$.

In general, higher values of $\mathrm{BE}$ can be found for similar tests performed with several biodegradable polymers. Kijchavengkul et al. (2008) found $\mathrm{BE}=60 \%$ for PBAT films after 45 days of the respirometric test. Funabashi et al. (2009) tested biopolymers such as PCL and PLA in powder form and found BE close to $80 \%$ for 45 days and $100 \%$ for 70 days of the test. The same authors still tested PLA plates that were completely degraded $(\mathrm{BE}=100 \%)$ after nearly 140 days of test (Funabashi et al., 2009). Muniyasamy et al. (2013) found $\mathrm{BE}=90 \%$ for PBAT in powder after 190 days and even higher BE, about $100 \%$, for blends of PBAT with distillers dried grains.

The packaging tested in this study has not reached BE as high as those found in the literature. The likely reason for this lies in the microbial activity level of the compost. International Organization for Standardization (2007) recommends checking the activity of the inoculum in order to validate it. Basically, two respirometric pre-tests are conducted: (1) a reactor containing the compost and the positive reference material; and (2) a control reactor, containing only the compost. Inoculum validation consists of two 
conditions: (i) the treatment with the reference material shall reach $\mathrm{BE} \geq 70 \%$ at the end of the test; and (ii) the control shall evolve between 50 and $150 \mathrm{mg}$ of $\mathrm{CO}_{2}$ per gram of volatile solids during the first 10 days of the test. Both checks failed for this study: sucrose - positive reference material chosen - reached half the recommended $\mathrm{BE}(35 \%)$; and the compost in the control reactors evolved on average $31.04 \mathrm{mg}$ of $\mathrm{CO}_{2}$ per gram of volatile solids up to 10DAI. Therefore, the existing microbiota in the chosen compost was not particularly active, thus consisting of an inoculum less efficient than what is recommended by the standard (International Organization for Standardization, 2007).

A second reason for the low BE values is related to the incubation time. It can be noted that some tests found in the literature were held for about 200 days, following recommendations of International Organization for Standardization (2007), which affirms that the tests can be extended until BE reaches a plateau phase. Besides the low microbial activity of the inoculum, it can be seen from Figure 3 that at the end of the 47 days of test, either the sucrose (T1) or PBAT/starch film (T3) were still at an ascending phase, which indicates that they could have reached even higher BE if the test had continued.

\subsection{Thermic and structural analyses}

\subsubsection{Fourier Transform Infrared Spectroscopy (FTIR)}

The infrared spectra obtained for the samples of polymers before and after being subjected to respirometric tests are illustrated in Figure 3. It was not possible to verify alterations of any peak after the biodegradation of the polymers, even for the biodegradable ones. This does not mean, however, that there was no degradation on these materials but only that the process which they were subjected to did not promote breaks in molecules structure that could be detected by infrared analyses.
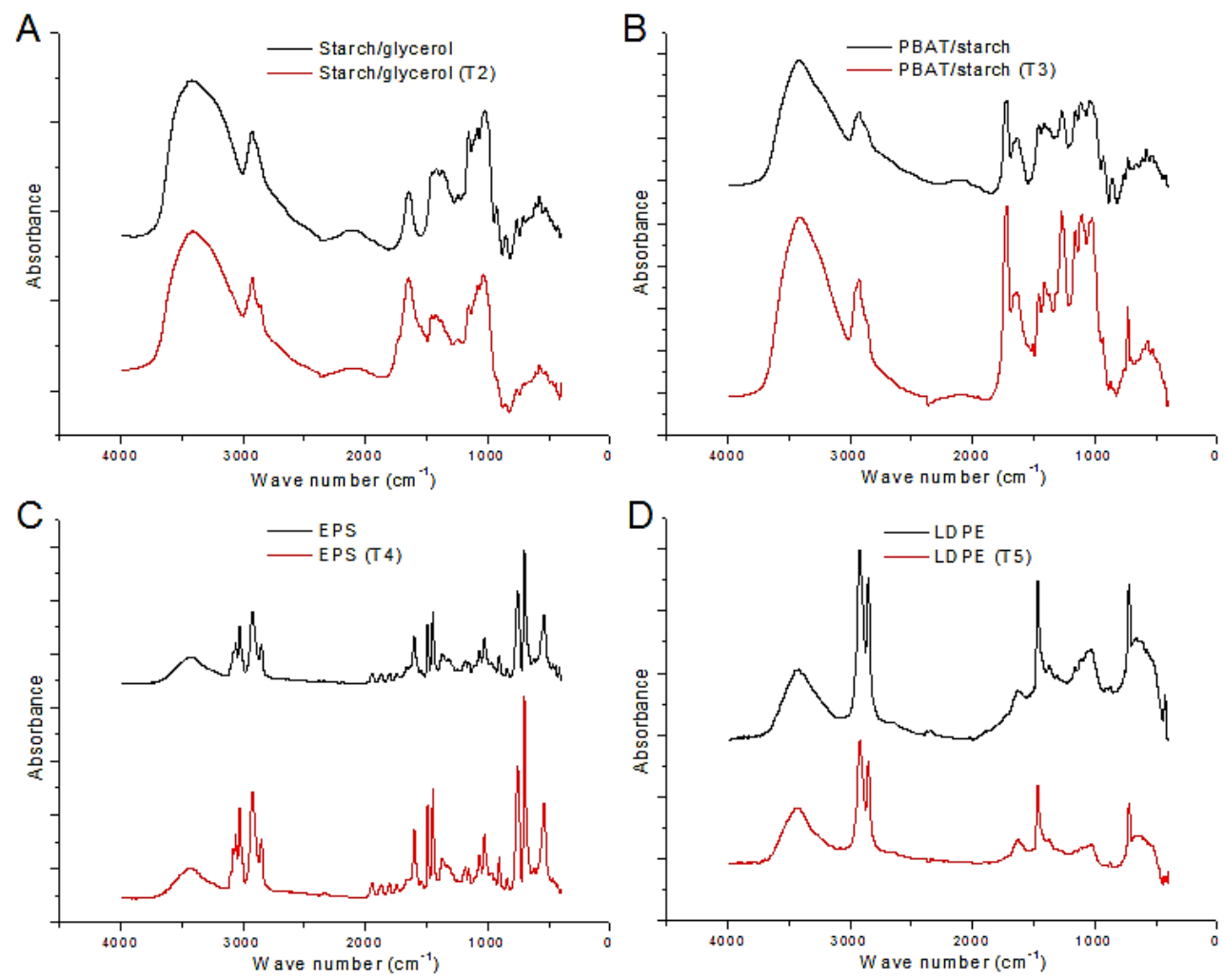

Figure 3. FR-IT spectra for starch/glycerol (A), PBAT/starch (B), EPS (C) and LDPE (D) before (black) and after (red) biodegradation process. 
A likely explanation for it not being possible to verify the degradation of the biodegradable polymers by means of the FTIR spectra is due to the composition of the starch, considering that the largest portion of both biodegradable packaging materials consists of this compound. The molecules of a synthetic polymer, for instance, are attacked by microorganisms initially in specific and more vulnerable parts of their structure, and then the most complex parts are degraded. On the other hand, glucose molecules, such as starch, are completely degraded at the surface of the material. Therefore, the samples after biodegradation consist of the most internal layers, which remain intact, with no alteration in the structure, and likely for this reason, it is not possible to detect variation on peaks of the FTIR spectra. Ki \& Ok Park (2001) studied the biodegradability of several biodegradable polyesters and reported that soluble compounds that are close to the surface can escape from the polymeric matrix before total degradation while those located inside the matrix can hardly diffuse out the matrix; possibly, this occurred with starch/glycerol and PBAT/starch blend.

\subsubsection{Thermogravimetric analysis}

The TGA curves for the biodegradable packaging (T2 and T3) in the study are illustrated in Figure 4A, B, respectively. On assessing TGA and DTGA curves for starch/glycerol (Figure 4A), it can be seen that after degradation, the temperature $T_{\text {máx }}$ - i.e. the temperature at the maximum mass loss rate - remains nearly the same. This means that the thermal stability of the biopolymer has not been affected after the experiments, which confirms that the starch that was in the surface of the foams was degraded, but the material that was in the internal layers remained intact.

The decrease in the amplitude of the peak after biodegradation could be due to existing impurities in the samples. Washing techniques usually used to remove remaining inoculum from the samples could not be applied in this case because high contents of starch confer high solubility to the samples, which would be completely dissolved under running water. A dry-cleaning method was used instead, but little trace of compost could still be visually observed on the samples surface before TGA analysis. In the presence of impurities, the char content increases, and the loss in mass of the starch represents a smaller portion of the total loss of the sample, which explains the lower peak after biodegradation - Figure 4A.

It can be still seen that DTGA curve for the PBAT/starch film (Figure 4B) showed two distinct peaks, which characterizes a blend between two materials. Paula \& Mano (2012) also found distinct peaks for poly(D,L)lactide (PDLLA) and polyvinylpyrrolidone (PVP) when coexistent in a blend. The peak related to starch can be identified at about $330{ }^{\circ} \mathrm{C}\left(\mathrm{T}_{\text {máx }}=330{ }^{\circ} \mathrm{C}\right)$, the same peak observed for starch/glycerol in Figure 4A. PBAT is then related to the peak $\mathrm{T}_{\text {máx }}=412^{\circ} \mathrm{C}$, close to the value found by Muniyasamy et al. (2013) when testing pure PBAT. 

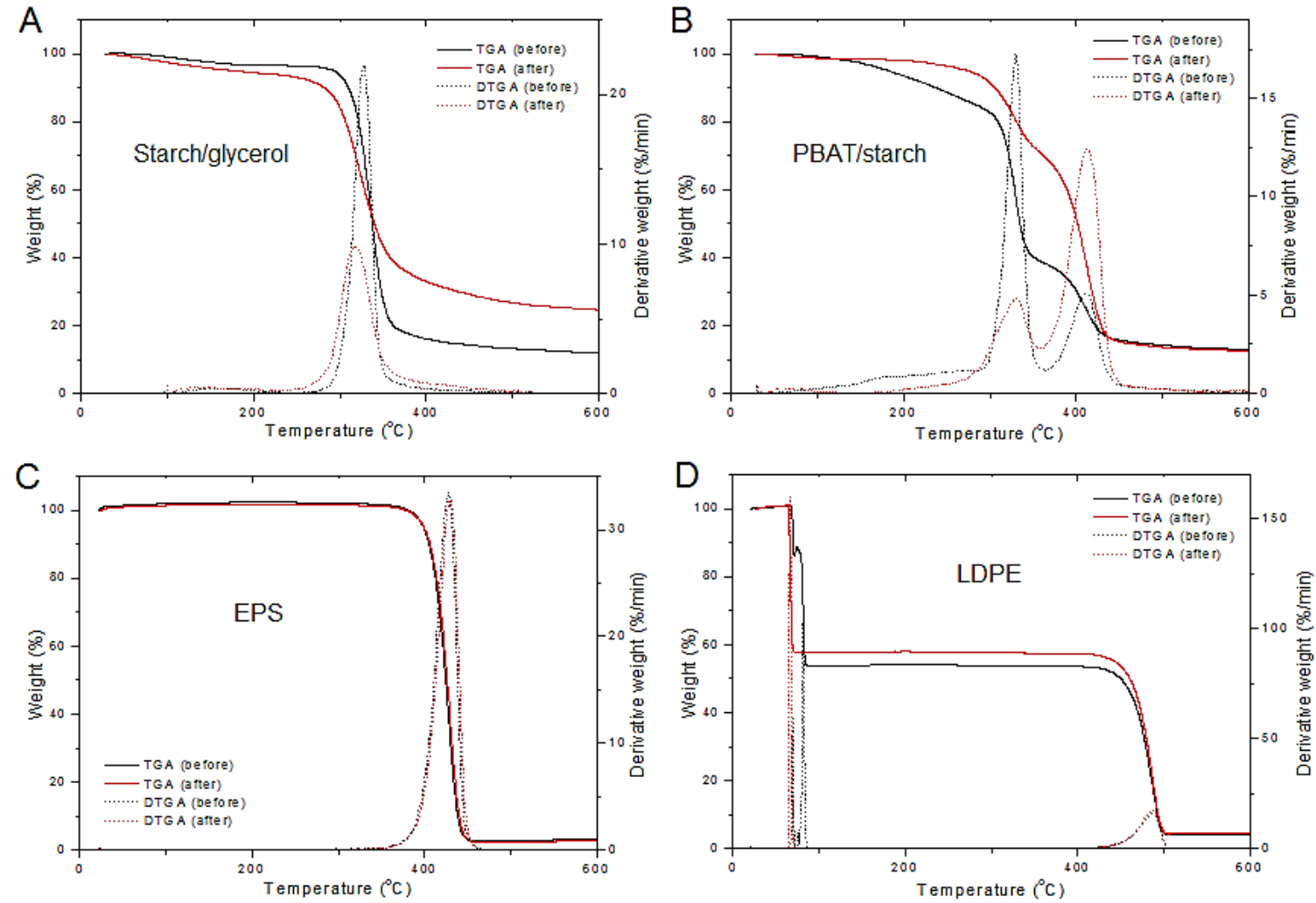

Figure 4. TGA (continuous) and DTGA (dashed) curves for starch/glycerol (A), PBAT/starch (B), EPS (C) and LDPE (D) before (black) and after (red) respirometric tests.

It is observed at the DTGA curve for PBAT/starch film (Figure 4B) that the peak related to starch remains after biodegradation, but the loss in mass is much less significant. On the other hand, for the peak related to PBAT, it works otherwise: after biodegradation, there is higher loss in mass, represented by the higher peak amplitude. This inversion on both peaks' amplitudes can be explained considering that microorganisms rather degraded the starch existing in the blend surface. Therefore, the starch/PBAT ratio is much smaller after biodegradation and PBAT consists of the largest portion of the degraded blend sample. Thus, during TGA analyses, the little mass of starch remaining is thermally degraded at $330^{\circ} \mathrm{C}$, generating a lower peak than before biodegradation, and PBAT in turn, is thermally degraded at $412{ }^{\circ} \mathrm{C}$, generating a higher peak, since it represents now a larger portion of the sample in mass. This lower peak at $330{ }^{\circ} \mathrm{C}$ for starch corroborates that starch in the film surface was easily degraded, but starch that was in the internal polymeric matrix was still intact at the end of the tests (same $T_{\text {máx }}$ than before degradation).

It can be seen that, as expected, there is no change in thermal stability of EPS tray - T4 (Figure 4C), since either TGA or DTGA curves are very close for samples before and after the tests. On the other hand, the curves for the LDPE bag (T5) shift a little after degradation (Figure 4D) and hence do not overlap as for EPS. Moreover, there are two distinct peaks as there were for the PBAT/starch blend. However, LDPE does not consist of a blend and the existence of two peaks is not reported in other studies for the same material. Conventional TGA curves for LDPE found in literature show only one peak at about $\mathrm{T}_{\text {máx }}=460{ }^{\circ} \mathrm{C}$, which was also detected on the curves in Figure 4D (Waldman, 1996; Puti et al., 2013). Therefore, this peak could correspond to pure LDPE and other peaks correspond to some contamination in the samples that can have occurred during the manipulation of the bags. 


\section{Conclusion}

Both biodegradable packaging - starch/glycerol tray and PBAT/starch film - presented good performance regarding $\mathrm{CO}_{2}$ evolution, being statistically equal to sucrose emissions. Final biodegradation efficiencies were $34 \%$ and $38 \%$ for starch/glycerol foam and PBAT/starch film, respectively, and even higher values could be expected for the latter for longer tests considering the ascending behavior of its BE curve at the end of the 47 days. Both conventional packaging - EPS tray and LDPE bag - did not degrade considering that $\mathrm{CO}_{2}$ evolution for both treatments was lower than control.

From FTIR and TGA results, it was concluded that the microbiota rather degraded the starch in the surface of the polymeric matrix over the PBAT in the PBAT/starch blend, and also that some starch remained intact in the internal polymeric matrix. Finally, it was concluded that both biodegradable packaging materials in the test present good biodegradability degrees. It may then be feasible to utilize PBAT/starch bags for disposing of organic residential waste, as well as discard starch/glycerol trays along with these residues when there are composting facilities nearby. However, compostability tests for these packaging materials should be carried out in future studies in order to evaluate their behavior when in contact with organic waste and other compostable residues and hence to prove the feasibility of such waste management policies.

\section{Acknowledgements}

The authors thank the Federal University of Technology - Parana for funding. We also appreciate the collaboration of researchers from the Department of Biochemistry and Biotechnology and the Department of Food Science and Technology (State University of Londrina) for developing and supplying all the biodegradable packaging.

\section{References}

Ahmed, S., \& Ikram, S. (2016). Chitosan and gelatin based biodegradable packaging films with UV-light protection. Journal of Photochemistry and Photobiology. B, Biology, 163, 115-124. PMid:27560490. http://dx.doi.org/10.1016/j.jphotobiol.2016.08.023

American Public Health Association - APHA. American Water Works Association - AWWA. Water Environment Federation WEF. (2012). Standard methods for the examination of water and wastewater (22th ed.). Washington: APHA.

Associação Brasileira de Normas Técnicas - ABNT. (2008). NBR 15448-1: Embalagens plásticas degradáveis e/ou de fontes renováveis. Parte 1: Terminologia. Rio de Janeiro: ABNT.

Belgacem, M. N., \& Gandini, A. (2008). The state of the art. In M. N. Belgacem \& A. Gandini (Eds.), Monomers, polymers and composites from renewable resources. Oxford: Elsevier.

Bonilla, J., Talón, E., Atarés, L., Vargas, M., \& Chiralt, A. (2013). Effect of the incorporation of antioxidants on physicochemical and antioxidant properties of wheat starch-chitosan films. Journal of Food Engineering, 118(3), 271-278. http://dx.doi.org/10.1016/j.jfoodeng.2013.04.008

Brandelero, R. P. H., Grossmann, M. V. E., \& Yamashita, F. (2013). Hidrofilicidade de filmes de amido/poli(butileno adipato cotereftalato) (PBAT) adicionados de Tween 80 e óleo de soja. Polímeros, 23, 270-275. http://dx.doi.org/10.1590/S010414282013005000011

Brito, G. F., Agrawal, P., Araújo, E. M., \& Melo, T. J. A. (2011). Biopolímeros, polímeros biodegradáveis e polímeros verdes. Revista Eletrônica de Materiais e Processos, 6(2), 127-139. Retrieved in 2013, December 19, from http://cct.ufcg.edu.br/revista/index.php/REMAP/article/viewFile/222/204

Campos, C. A., Gerschenson, L. N., \& Flores, S. K. (2011). Development of edible films and coatings with antimicrobial activity. Food and Bioprocess Technology, 4(6), 849-875. http://dx.doi.org/10.1007/s11947-010-0434-1

Cardoso, M. A., Carvalho, G. M., Yamashita, F., Mali, S., Eiras, D., Demiate, I. M., \& Grossmann, M. V. E. (2018). Oat hull fibers bleached by reactive extrusion with alkaline hydrogen peroxide in thermoplastic starch/poly(butylene adipate-co-terephthalate) composites. Polymer Composites, 39(6), 1950-1958. http://dx.doi.org/10.1002/pc.24151

Carmo, D. L., \& Silva, C. A. (2012). Métodos de quantificação de carbono e matéria orgânica em resíduos orgânicos. Revista Brasileira de Ciência do Solo, 36(4), 1211-1220. http://dx.doi.org/10.1590/S0100-06832012000400015

Carvalho, F. A., Bilck, A. P., Yamashita, F., \& Mali, S. (2018). Baked foams based on cassava starch coated with polyvinyl alcohol with a higher degree of hydrolysis. Journal of Polymers and the Environment, 26(4), 1445-1452. http://dx.doi.org/10.1007/s10924-017-1046-x 
Chiou, B. S., Glenn, G. M., Imam, S. H., Inglesby, M. K., Wood, D. F., \& Orts, W. J. (2005). Starch polymers: Chemistry, engineering, and novel products. In A. K. Mohanty, M. Misra \& L. T. Drzal (Eds.), Natural fibers, biopolymers, and biocomposites. Boca Raton: Taylor \& Francis. http://dx.doi.org/10.1201/9780203508206.ch20.

Debiagi, F., Marim, B. M., \& Mali, S. (2015). Properties of cassava bagasse and polyvinyl alcohol biodegradable foams. Journal of Polymers and the Environment, 23(2), 269-276. http://dx.doi.org/10.1007/s10924-014-0705-4

Frackowiak, S., Ludwiczak, J., Leluk, K., \& Kozlowski, M. (2016). New class of shear oriented, biodegradable packaging material. Composites. Part B, Engineering, 92, 1-8. http://dx.doi.org/10.1016/j.compositesb.2016.02.036

Funabashi, M., Ninomiya, F., \& Kunioka, M. (2009). Biodegradability evaluation of polymers by ISO 14855-2. International Journal of Molecular Sciences, 10(8), 3635-3654. PMid:20111676. http://dx.doi.org/10.3390/ijms10083635

Garcia, P. S., Baron, A. M., Yamashita, F., Mali, S., Eiras, D., \& Grossmann, M. V. E. (2018). Compatibilization of starch/poly(butylene adipate-co-terephthalate) blown films using itaconic acid and sodium hypophosphite. Journal of Applied Polymer Science, 135(33), $46629 \mathrm{http}: / / \mathrm{dx}$. doi.org/10.1002/app.46629

Garcia, P. S., Grossmann, M. V. E., Shirai, M. A., Lazaretti, M. M., Yamashita, F., Muller, C. M. O., \& Mali, S. (2014). Improving action of citric acid as compatibiliser in starch/polyester blown films. Industrial Crops and Products, 52, 305-312. http://dx.doi.org/10.1016/j.indcrop.2013.11.001

Halley, P. F. (2005). Thermoplastic starch biodegradable polymers. In R. Smith (Ed.), Biodegradable polymers for industrial application. Cambridge: Woodhead Publishing.

Harun-Or-Rashid, M. D., Saifur Rahaman, M. D., Enamul Kabir, S., \& Khan, M. A. (2015). Effect of hydrochloric acid on the properties of biodegradable packaging materials of carboxymethylcellulose/poly(vinyl alcohol) blends. Journal of Applied Polymer Science, 133, 1-11.

International Organization for Standardization - ISO. (2007). ISO 14855-2: Determination of the ultimate aerobic biodegradability of plastic materials under controlled composting conditions: Method by analysis of evolved carbon dioxide. Part 2: Gravimetric measurement of carbon dioxide evolved in a laboratory-scale test.

Kawazaki, L. I., Miyazawa, M., Pavan, M. A., \& Franchini, J. C. (2000). Determinação condutométrica de carbonato residual do calcário aplicado no solo por análise em fluxo. Quimica Nova, 23(4), 560-562. http://dx.doi.org/10.1590/S010040422000000400021

Ki, H. C., \& Ok Park, O. (2001). Synthesis, characterization and biodegradability of the biodegradable aliphatic-aromatic random copolyesters. Polymer, 42(5), 1849-1861. http://dx.doi.org/10.1016/S0032-3861(00)00466-3

Kiehl, E. J. (2004). Manual da compostagem: Maturação e qualidade do composto. Piracicaba.

Kijchavengkul, T., Auras, R., Rubino, M., Ngouajio, M., \& Thomas Fernandez, R. (2006). Development of an automatic laboratory-scale respirometric system to measure polymer biodegradability. Polymer Testing, 25(8), 1006-1016. http://dx.doi.org/10.1016/j.polymertesting.2006.06.008

Kijchavengkul, T., Auras, R., Rubino, M., Ngouajio, M., \& Fernandez, R. T. (2008). Assessment of aliphatic-aromatic copolyester biodegradable mulch films. Part II: Laboratory simulated conditions. Chemosphere, 71(9), 1607-1616. PMid:18353427. http://dx.doi.org/10.1016/j.chemosphere.2008.01.037

Krishnan, S., Mohanty, S., \& Nayak, S. K. (2017). Renewable Resource based blends of Polylactic acid (PLA) and Thermoplastic starch (TPS) using Novel Reactive Compatibilization. Journal of Polymer Materials, 34(3), 525-538. Retrieved in 2019, August 3, from http://search-ebscohost-

com.ez78.periodicos.capes.gov.br/login. aspx?direct=true\&db=aph\&AN=127425218\&lang=pt-br\&site=eds-live

Li, G., Sarazin, P., Orts, W. J., Imam, S. H., \& Favis, B. D. (2011). Biodegradation of thermoplastic starch and its blends with Poly(lactic acid) and polyethylene: Influence of morphology. Macromolecular Chemistry and Physics, 212(11), 1147-1154. http://dx.doi.org/10.1002/macp.201100090

Malavolta, E., Vitti, G. C., \& Oliveira, S. A. (1997). Avaliação do estado nutricional das plantas: Princípios e aplicações (2. ed.). Piracicaba: Potafos.

Marcelino, P. R. F., Milani, K. M. L., Mali, S., Santos, O. J. A. P., \& Oliveira, A. L. M. (2016). Formulations of polymeric biodegradable low-cost foam by melt extrusion to deliver plant growth-promoting bacteria in agricultural systems. Applied Microbiology and Biotechnology, 100(16), 7323-7338. PMid:27147530. http://dx.doi.org/10.1007/s00253-016-7566-9

Marengo, V. A., Vercelheze, A. E. S., \& Mali, S. (2013). Compósitos biodegradáveis de amido de mandioca e resíduos da agroindústria. Quimica Nova, 36(5), 680-685. http://dx.doi.org/10.1590/S0100-40422013000500012

Matsuda, D. K. M., Verceheze, A. E. S., Carvalho, G. M., Yamashita, F., \& Mali, S. (2013). Baked foams of cassava starch and organically modified nanoclays. Industrial Crops and Products, 44, 705-711. http://dx.doi.org/10.1016/j.indcrop.2012.08.032

Mello, L. R. P. F., \& Mali, S. (2014). Use of malt bagasse to produce biodegradable baked foams madefrom cassava starch. Industrial Crops and Products, 55, 187-193. http://dx.doi.org/10.1016/j.indcrop.2014.02.015

Muniyasamy, S., Reddy, M. M., Misra, M., \& Mohanty, A. (2013). Biodegradable green composites from bioethanol co-product and poly(butylene adipate-co-terephthalate). Industrial Crops and Products, 43, 812-819. http://dx.doi.org/10.1016/j.indcrop.2012.08.031

Nobrega, M. M., Olivato, J. B., Müller, C. M. O., \& Yamashita, F. (2013). Addition of saturated fatty acids to biodegradable films: Effect on the crystallinity and viscoelastic characteristics. Journal of Polymers and the Environment, 21(1), 166-171. http://dx.doi.org/10.1007/s10924-012-0477-7

Noorizzaha, I., Kahar, A. W. M., \& Uylana, D. N. (2016). Mechanical and physical properties of Polylactic Acid (PLA)/Thermoplastic Starch (TPS) blends. Journal of Polymer Materials, 33(1), 201-212. Retrieved in 2019, August 3, from 
http://search-ebscohost-com.ez78.periodicos.capes.gov.br/login.aspx?direct=true\&db=aph\&AN=115156109\&lang=ptbr\&site=eds-live

Olivato, J. B., Grossmann, M. V. E., Bilck, A. P., Yamashita, F., \& Oliveira, L. M. (2013). Starch/polyester films: Simultaneous optimisation of the properties for the production of biodegradable plastic bags. Polímeros, 23(1), 32-36. http://dx.doi.org/10.1590/S0104-14282013005000017

Olivato, J. B., Müller, C. M. O., Carvalho, G. M., Yamashita, F., \& Grossmann, M. V. E. (2014). Physical and structural characterisation of starch/polyester blends with tartaric acid. Materials Science and Engineering C, 39, 35-39. PMid:24863194. http://dx.doi.org/10.1016/j.msec.2014.02.020

Paula, E. L., \& Mano, V. (2012). Preparação, caracterização e estudos de biodegradação de blendas à base de PDLLA e PVP. Química Nova, 35(6), 1084-1089. http://dx.doi.org/10.1590/S0100-40422012000600003

Puti, F. C., Becaro, A. A., Correa, D. S., \& Ferreira, M. D. (2013). Caracterização das propriedades de filme comercial de PEBD com adição de nanopartículas de prata. In Anais do $12^{\circ}$ Congresso Brasileiro de Polímeros. Florianópolis. Retrieved in 2014, November 20, from http://www.eventweb.com.br/cbpol/specific-files/manuscripts/index.php?file=cbpol/17084_1370643463.pdf

Razza, F., Degli Innocenti, F., Dobon, A., Aliaga, C., Sanchez, C., \& Hortal, M. (2015). Environmental profile of a bio-based and biodegradable foamed packaging prototype in comparison with the current benchmark. Journal of Cleaner Production, 102, 493500. http://dx.doi.org/10.1016/j.jclepro.2015.04.033

Silva, A., Nievola, L. M., Tischer, C. A., Mali, S., \& Faria-Tischer, P. C. S. (2013). Cassava starch-based foams reinforced with bacterial cellulose. Journal of Applied Polymer Science, 130(5), 3043-3049. http://dx.doi.org/10.1002/app.39526

Tedesco, M. J., Gianello, C., Bissani, C. A., Bohnen, H., \& Volkweiss, S. J. (1995). Análises de solo, plantas e outros materiais (2. ed.). Porto Alegre: Departamento de Solos, UFRGS.

Vercelheze, A. E. S., Oliveira, A. L. M., Rezende, M. I., Muller, C. M. O., Yamashita, F., \& Mali, S. (2013). Physical properties, photo- and bio-degradation of baked foams based on cassava starch, sugarcane bagasse fibers and montmorillonite. Journal of Polymers and the Environment, 21(1), 266-274. http://dx.doi.org/10.1007/s10924-012-0455-0

Versino, F., Lopez, O. V., Garcia, M. A., \& Zaritzky, N. E. (2016). Starch-based films and food coatings: An overview. Stärke, 68(11-12), 1026-1037. http://dx.doi.org/10.1002/star.201600095

Vinhas, G. M., Almeida, Y. M. B., Lima, M. A. G. A., \& Santos, L. A. (2007). Estudo das propriedades e biodegradabilidade de blendas de poliéster/amido submetidas ao ataque microbiano. Química Nova, 30(7), 1584-1588.

http://dx.doi.org/10.1590/S0100-40422007000700016

Waldman, W. R. (1996). Degradação térmica e mecânica de polipropileno isotático (PPi), polietileno de baixa densidade (PEBD) e blenda 1:1 em massa de PPi e PEBD (Dissertação de mestrado). Universidade Estadual de Campinas, Campinas.

Weng, Y., Jin, Y., Meng, Q., Wang, L., Zhang, M., \& Wang, Y. (2013). Biodegradation behavior of poly(butylene adipatecoterephthalate) (PBAT), poly(lactic acid) (PLA), and their blend under soil conditions. Polymer Testing, 32(5), 918-926. http://dx.doi.org/10.1016/j.polymertesting.2013.05.001 